\title{
Selection of Key Standards to Create an Instrument for Information Literacy Assessment in Compulsory Secondary Education
}

\author{
Marcos Bielba Calvo \\ University of Salamanca \\ Paseo de Canalejas, 169 \\ Salamanca 37008 (Spain) \\ +34923294634 (ext.3461) \\ mbielba@usal.es
}

\author{
Fernando Martínez-Abad \\ University of Salamanca \\ Paseo de Canalejas, 169 \\ Salamanca 37008 (Spain) \\ +34923294634 (ext.3461) \\ fma@usal.es
}

\author{
$M^{a}$ Esperanza Herrera García \\ University of Salamanca \\ Paseo de Canalejas, 169 \\ Salamanca 37008 (Spain) \\ +34923294634 (ext.3351) \\ espe@usal.es
}

\begin{abstract}
The proposal presented here is a research project integrated into the framework of the $\mathrm{R}+\mathrm{D}+\mathrm{i}$ EDU 2012-34000, which plans to carry out an assessment of the development of key competences in students and teachers who belong to Secondary Education, and to implement formative programs for the development of key competences based on the use of ICT.
\end{abstract}

This study aims to validate an assessment instrument that measures the current level of information literacy based on international standards and adapted to the Spanish curriculum, for students who belong to the second cycle of Compulsory Secondary Education.

In the first phase, the research shows the process of compilation of rules handbooks published that are related to the information literacy. Together with the comparison between the table of specifications, the curriculum of Compulsory Secondary Education in Spain, which results in 42 standards, and the selection of key standards with numeric criteria.

From the application of a non-experimental design of type expost-facto, it shows the standards finally selected at the end of the valuation process based on three criteria: international standards, curricular aspects and valuation on behalf of highly qualified judges.

\section{Categories and Subject Descriptors}

K.3.2 [Computer and Information Science Education]: Language Constructs and Features - Curriculum, Literacy, Information systems education.

\section{General Terms}

Measurement

\section{Keywords}

Key competences, Digital Competence, Information Literacy,

Permission to make digital or hard copies of all or part of this work for personal or classroom use is granted without fee provided that copies are not made or distributed for profit or commercial advantage and that copies bear this notice and the full citation on the first page. To copy otherwise, or republish, to post on servers or to redistribute to lists, requires prior specific permission and/or a fee.

TEEM '14, October 01 - 03 2014, Salamanca, Spain.

Copyright is held by the owner/author(s). Publication rights licensed to ACM ACM 978-1-4503-2896-8/14/10 ..\$15.00.

http://dx.doi.org/10.1145/2669711.2669942
Curriculum, Secondary Education, Elementary Education, Information and Communication Technology, Assessment.

\section{INTRODUCTION}

As a consequence of the generalization of Information and Communication Technologies (ICT) has occurred an informational ecosystem [19], where the individual is constantly exposed to an information overload [49]. This process of informative abundance or "information explosion" [12] is considered by some authors as an illness [7, 26, 32, 46, 48, 51], using terms such as "information fatigue syndrome", infoglut or infobesity. Due to this informational phenomenon, it is necessary to acquire information literacy to give answer to these problems.

CRUE-REBIUN [15] defines the term information literacy "as the acquisition on behalf of the student of the following skills: the student searches the information he needs; he analyzes the information and selects it efficiently; the student organizes the information suitably; the student uses and communicates the information effectively in an ethical and legal way with the intention of constructing knowledge".

Another possible definition of information literacy is provided by the American Association of Schools Librarians [38] and the Association of College \& Research Libraries [4], which define it as "a set of abilities requiring the individuals to recognize when the information is needed and the ability to identify, locate, evaluate, organize, communicate and use the information efficiently".

Inside the educative framework, the Organic Law on Education (LOE) [28], as part of its prescriptive curriculum, establishes 8 key competences: language competence, mathematical competence, competence of knowledge and interaction with the physic world, digital competence, social and civic competence, culture and art competence, competence learning to learn and competence of autonomy and personal initiative.

These competences are within the European Framework of Key Competences performed by the European Parliament and the European Council [18], where it is set a reference framework with the intention of facilitating and encouraging an educative system based on the skills training.

Despite the curricular change produced by the approval and publication of the Organic Law on the Improvement of the Quality of Education (LOMCE) [29], there are not changes with respect to the model based on competences, which will be structured by the 3 main components: know, know-how, know-be $[17,30]$. 


\section{Second International Conference on Technological Ecosystems for Enhancing Multiculturality - TEEM'14}

Regarding the information literacy within the educative framework, these competences are collected inside the Information Literacy Treatment and Digital Competence (TIDI), and they are defined as "the abilities to search, obtain, process and communicate information and to transform it in knowledge. It has different abilities, from the access to the information to its transmission in different media, including the use of Information and Communication Technologies as main element to inform, learn and communicate". [31]

Calvani, Cartelli, Fini and Ranieri [13] say that "is being able to explore and face new technological situations in a flexible way to analyze, select and critically evaluate data and information, to exploit technological potentials in order to represent and solve problems and build shared and collaborative knowledge, while fostering awareness of one's own personal responsibilities and the respect of reciprocal rights/obligations".

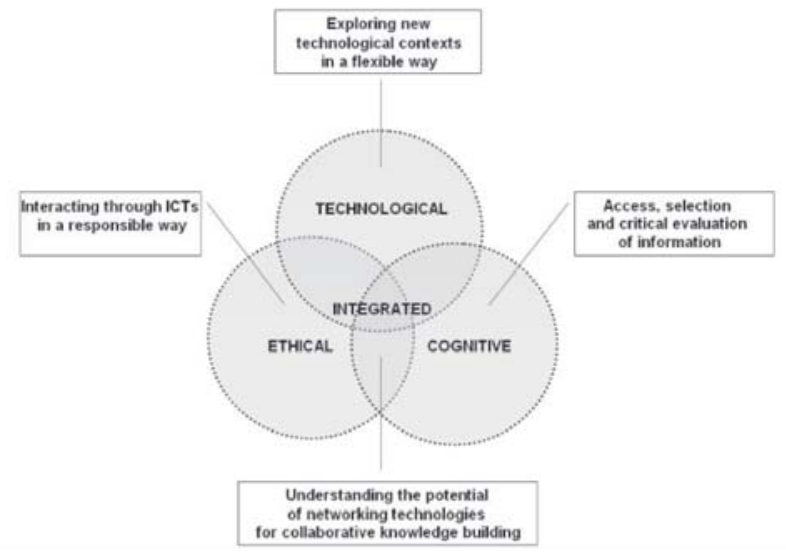

Figure 1. Digital Competence Framework. Taken from Calvani, Cartelli, Fini and Ranieri [13]

On the other hand, a report [20] has recently been published from the European Commission with the main descriptors of digital competence, which includes the information area as a priority. This topic has been worked not only from Europe, but also other international institutions are re-specifying the digital competence descriptors. At the same way, the Ministry of Education, Culture and Sport in Spain is also researching about this topic and it published a Guide about key competences [31] for the training in schools.

Regarding scientific researches about the design and implementation of instruments for the assessment about the level obtained in information literacy, appear a lot of studies [6, 22, 23, $27,39,45]$, although it is not the best way. They are researches which have been elaborated and applied in a scale type "ad hoc" without previous validation or validated scales but from the autoperception of the own competence [36, 42].

Although the information literacy is causing a strong impact in the scientific literature [37, 40,41, 43, 50], at the national level, beyond the definition and the transmission of the own information literacy $[15,16]$, there are not projects to design an assessment instrument of the real information literacy.

As well, most of researches are focused on the university field, although there are some of them which are focused on the information literacy in Elementary Education but paying attention to specific dimensions $[21,24,35]$.

This is the reason by which this project pretends to open a new line of research about the assessment of key competences, specifically, about the information literacy at the second cycle of Compulsory Secondary Education.

The lack of researches focused on Elementary Education together with the development of the students' autonomy in the search, assessment, process and communication of the information [10], as well as their cognitive level $[33,34]$ coincide with the stage of formal operations which are able to develop the abstraction on specific knowledge. The entire above are strong reasons to focus the research on the second cycle of Compulsory Secondary Education.

Another important reason to select this educative stage and this age range is the application of some international diagnostic assessments such as PISA (Program for International Student Assessment), which applies an assessment instrument to students who are between 14-16 years old.

As said above, there are a few researches about information literacy at the national level, despite the efforts carried out by CRUE-TIC \& CRUE-REBIUN $[15,16]$ translating and adapting international handbooks (Handbook for Information Literacy Teaching, published by the Cardiff University).

However, at the international level, there are some handbooks in order to design assessment instruments in information competences $[1,3,5,14,25,47]$, although these are shown as contradictory in some of the dimensions and performance standards.

In short, this project wants to carry out an initial selection of the key standards of information literacy based on international standards and adapted to the Spanish curriculum for students at the second cycle of Compulsory Secondary Education, with the aim of designing and validating an instrument to assess their current level in information literacy.

\section{AIMS}

The main aims of this research are to design and to validate an assessment instrument of information literacy in Secondary Education. The specific aims are the following:

- Designing a table of specifications with the dimensions, sub-dimensions and performance standards of information literacy from the review, unification and selection of standards from different handbooks.

- Doing an initial selection of the standards from the comparison between the table of specifications and the Spanish curriculum contents.

- Selecting the key standards from the relative importance that they have in the curriculum, its importance during the start-up process and the importance assigned by experts on assessment.

\section{METHOD}

\subsection{Design}

It is used a design of type non-experimental from studies of type descriptive-correlational with a methodology ex-post-facto.

\subsection{Sample}

For the development of the $3^{\text {rd }}$ phase (look up the process), 14 experts in information literacy who belong to different branches of knowledge (social sciences, computing, IT, documentation, library science, etc.) constitute the sample.

The sample selection is made through the authors' analysis of national or international scientific journals related to the 


\section{Selection of key standards to create an instrument for information literacy assessment in Compulsory Secondary Education}

information literacy (digital competence, information management...) and to the search of experts integrated into national or international committees about information literacy.

\subsection{Variables and instruments}

The instrument used to collect the data in this research (showed at figure 2) is a questionnaire carried out with Google Drive (specifically via Google Forms). For it, the first step is to design the instrument, whose variables are the 42 initial standards, selected from the review of handbooks and adapted to the level of Secondary Education in Spain, Likert-type (1 to 10) with the aim of evaluating the relevance of the information literacy standards for the Secondary Education students.

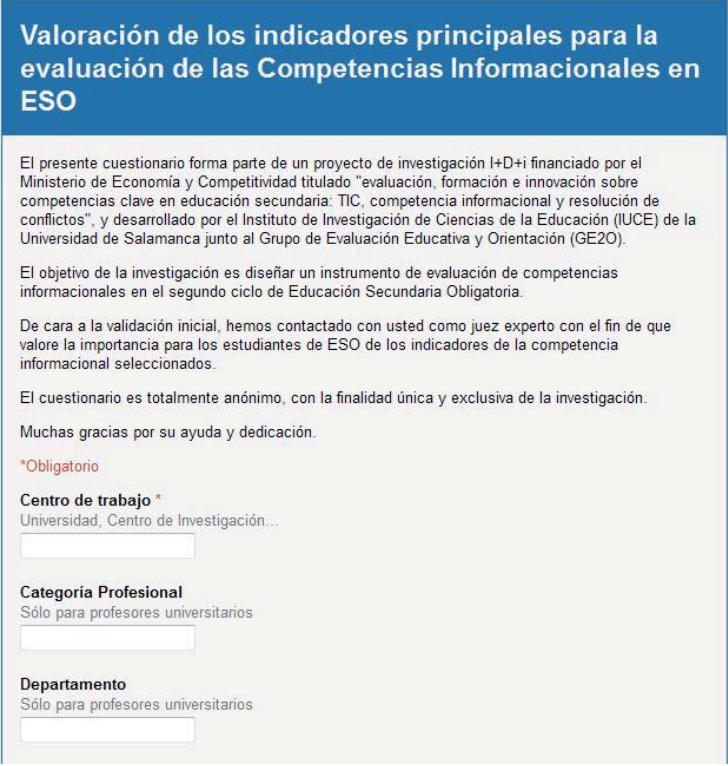

Figure 2. Questionnaire

\subsection{Procedure}

The process selection of the key standards to design and validate an assessment instrument of information literacy at Secondary Education has some phases:

Phase 1: The first step is to do a review of the different handbooks about information literacy, and then, to perform a table of specifications with the aim of comparing the standards that each handbook has. American Library Association (ALA) together with the Association of College \& Research Libraries (ACRL), Australian and New Zealand Institute for Information Literacy, (ANZIIL), Council of Australian University Librarians (CAUL), International Society for Technology in Education (ISTE), Society of College, National and University Librarians, (SCONUL) and CRUE-TIC \& REBIUN try to define the information literacy dimensions (search, process, assessment and communicate/share of the information) to extract the most appropriate standards to the research target.

Phase 2: The second phase consists in comparing the table of specifications and the Spanish curriculum in Secondary Education. It collects the criteria of the RD 1631/2006, on 29th of December, Basic Competences in Secondary Education, Digital Competence and Treatment of information. In them are established the core curriculum in Secondary Education and the standards of the Digital Competence and Treatment of information, collected within the "Guide to the training in educational centres about basic competences" that has recently been published by the Ministry of Education, Culture and Sport [31]. This guide allows seeing the relation between the aims and the content of the curriculum within the Secondary Education subjects.

So the curriculum is reviewed with the aim of knowing what the criteria of Spanish State about the information literacy in Secondary Education are, collected in Organic Law of Education (LOE). Through this process it is obtained a first score about the importance of each standard depending on the specific weighting that each of them has in the curriculum [28].

Phase 3: When the previous phases have been done, the next step is to create a flowchart in order to represent the main nodes (learning results in each phase with the development of the information literacy) and their relation. Moreover, it also allows the observation between the relations and the dimensions.

In this way, it is reviewed and later, the valid standards for the research are selected and sent to a corresponding node in order to obtain a flowchart. Through this process, it is obtained a second score about the importance of each learning result. The learning result is scored: 1 point if the node sent a link and 2 points if the node received a link.

Phase 4: Once finished the whole process, the last phase is to do a valuation of the standards by experts on that topic.

There are experts on Education Science, Librarianship \& Information Management, Psychology, IT... who value the standards chosen. Therefore, the third score will be the average obtained by each standard.

Through this way, the experts value from 1 to 9 the importance of each of the standards (42), which are related to the information literacy in Secondary Education.

Phase 5: It performs the calculation of percentiles by standardized scores, becoming in $\mathrm{Z}$ score and doing the weighted summation of these. The $25 \%$ refers to the connections established between the different learning results of the flowchart. Another 25\% refers to the comparison of the specification table and the curriculum in Secondary Education. Finally, the remaining $50 \%$ is extracted from the valuation made by expert judges.

\subsection{Data analysis}

In all phases, descriptive techniques such as the analysis of frequency tables and calculating the average, deviation and coefficient of variation, are used. The selection of final standards is proceeded from the calculation of percentiles from the weighted score of the three variables.

\section{RESULTS}

At the end of the first phase of the research, a table of specifications about the 4 dimensions of information literacy is obtained: search, assessment, process and share/communicate information. The need of information, cited in many handbooks, is considered as a constant dimension during the whole process of information, so it is included in all of them.

The final table is composed by 14 learning results and it contains 42 standards. The standards are related to the 4 dimensions of information literacy. 


\section{Second International Conference on Technological Ecosystems for Enhancing Multiculturality - TEEM'14}

\begin{tabular}{|c|c|c|}
\hline $\begin{array}{l}\text { Obtener información, } \\
\text { búsqueda, selección, registro y } \\
\text { tratamiento }\end{array}$ & $\begin{array}{l}\text { Transformar la información en } \\
\text { conocimiento }\end{array}$ & Comunicar la información \\
\hline $\begin{array}{l}\text { - Acceder a la información } \\
\text { utilizando técnicas y } \\
\text { estrategias especificas. } \\
\text { - Buscar, seleccionar, registrar, } \\
\text { tratary y analizar la información. } \\
\text { - Dominar y aplicar en distintas } \\
\text { situaciones y contextos } \\
\text { lenguajes específicos básicos: } \\
\text { textual, numérico, iconico, } \\
\text { visual, gráfico y sonoro. } \\
\text { - Dominar las pautas de } \\
\text { decodificación y transferencia. } \\
\text { - Aplicar en distintas situaciones } \\
\text { y contextos los diferentes } \\
\text { tipos de información, sus } \\
\text { fuentes, sus posibilidades y } \\
\text { su localización, asi como los } \\
\text { lenguajes y soportes más } \\
\text { frecuentes. } \\
\text { - Manejar estrategias para } \\
\text { Identficary resolver los } \\
\text { problemas habituales de } \\
\text { software y hardware. } \\
\text { - Hacer uso habitual de los } \\
\text { recursos tecnológicos } \\
\text { disponibles. }\end{array}$ & $\begin{array}{l}\text { - Organizar la información, } \\
\text { relacionarla, analizarla, } \\
\text { sintetizarla, hacer inferencias y } \\
\text { deducciones de distinto nivel } \\
\text { de complejiddad. } \\
\text { - Resolver problemas reales de } \\
\text { modo eficiente. } \\
\text { - Tomar decisiones. } \\
\text { - Trabajar en entornos } \\
\text { colaborativos. } \\
\text { - Conseguir objetivos y fines de } \\
\text { aprendizaje, trabajo y ocio. } \\
\text { - Evaluar y seleccionar nuevas } \\
\text { fuentes de información e } \\
\text { innovaciones tecnológicas } \\
\text { en función de su utilidad para } \\
\text { acometer tareas. } \\
\text { - Procesar y gestionar } \\
\text { adecuadamente la } \\
\text { información. } \\
\text { - Comprender e integrar la } \\
\text { información en los esquemas } \\
\text { previos de conocimiento. }\end{array}$ & $\begin{array}{l}\text { - Comunicar la información y los } \\
\text { conocimientos. } \\
\text { - Usar las tecnologías de la } \\
\text { información y la comunicación } \\
\text { como elemento esencial } \\
\text { para informarse, aprender y } \\
\text { comunicarse. } \\
\text { - Emplear diferentes recursos } \\
\text { expresivos además de las TIC. } \\
\text { - Utilizar las tecnologías de la } \\
\text { información y la comunicación } \\
\text { como instrumento de trabajo } \\
\text { intelectual (función transmisora } \\
\text { y generadora de información y } \\
\text { conocimientos). } \\
\text { - Generar producciones } \\
\text { responsables y creativas. }\end{array}$ \\
\hline
\end{tabular}

Figure 3. Treatment of Information and Digital Competence. Taken from Guía para la formación en centros sobre las competencias básicas [31]

Regarding the results obtained in the second phase, in which the descriptors shown in figure 3 and the 42 standards obtained are compared, it should be noted the learning result E2 (know assessment criteria) with 27 descriptors. Secondly, the standard B2 (know-how to do the search planning), B3 (know how to select information) and B4 (know to extract and manage the sources) with 18,18 and 15 descriptors each, respectively. C1 (understand and apply ethical standards) with 4 descriptors and E1 (apply and assess) with 7, appear in last position.

It can be observed that the dimension of information search predominates against other dimensions, including 3 learning results with a bigger number of descriptors, while the learning results of the dimension of information communication have fewer descriptors.

On the one hand, the standards that are composed by each learning results are shown. We can see that: the dimension of information search, whose standards have more descriptors $(9$ each) are the B3_09 (it uses various search systems to recover the information in different formats) and B3 10 (it uses the specialized services available at the institution to recover information needed personally or online). Both of them are included within the learning result B3

Regarding the dimension of information assessment, 3 standards belonging to the learning result E2 obtains the same number of descriptors (7 each). These standards are the following: E2 17 (examines and compares information from various sources to evaluate the reliability, validity, correction, authority, timeliness, and point of view or slant), E2_18 (identifies the aim and receivers of potential resources) and E2 20 (recognizes and puts into question the prejudice, deception, or manipulation).

Within the dimension of information process occurs an exceptional case due to the standard P3 28 (understand that knowledge is not static) does not register no descriptor into the Guide created by Ministry of Education, Science and Sport.

On the other hand, the standards P1_22 (organizes and relates the information available) and P1 23 (manages different ways to access the information) are the standards with more descriptors (7 each).
Finally, in the dimension of information communication, the standards with a bigger number of descriptors (6 each) are the standards C4 41 (communicate clearly with a style appropriate for the purposes of the hearing) and C4_42 (communicate objectively and respect the universally accepted values).

As regards to the average of each learning results, it is observed that the learning result B3 (know how to select information) obtains 9 descriptors per average. Conversely the learning result C1 (know how to understand and to apply ethical standards) is the learning result which obtains the worst average.

If those results are extrapolated towards the dimensions, the results are similar to the results from the standards. In first position, it is the dimension of information search while the dimension of information communication occupies the last position.

The obtained results in the third phase through the flow chart, (shown in figure 4) indicates that the learning result B2 is the node which sends and receives more links (2-5) based on the criteria established previously, with 12 points. The second place is occupied by B1 (2-4), C1 (4-3) and P2 (4-3), with 10 points, all of them. $\mathrm{P} 3$ and $\mathrm{B} 3$ are in last position (2-1) with a sum of 5 points.

As regards to the dimensions, the first is the information search dimension whose average is the highest, while the information assessment dimension obtains the lowest average.

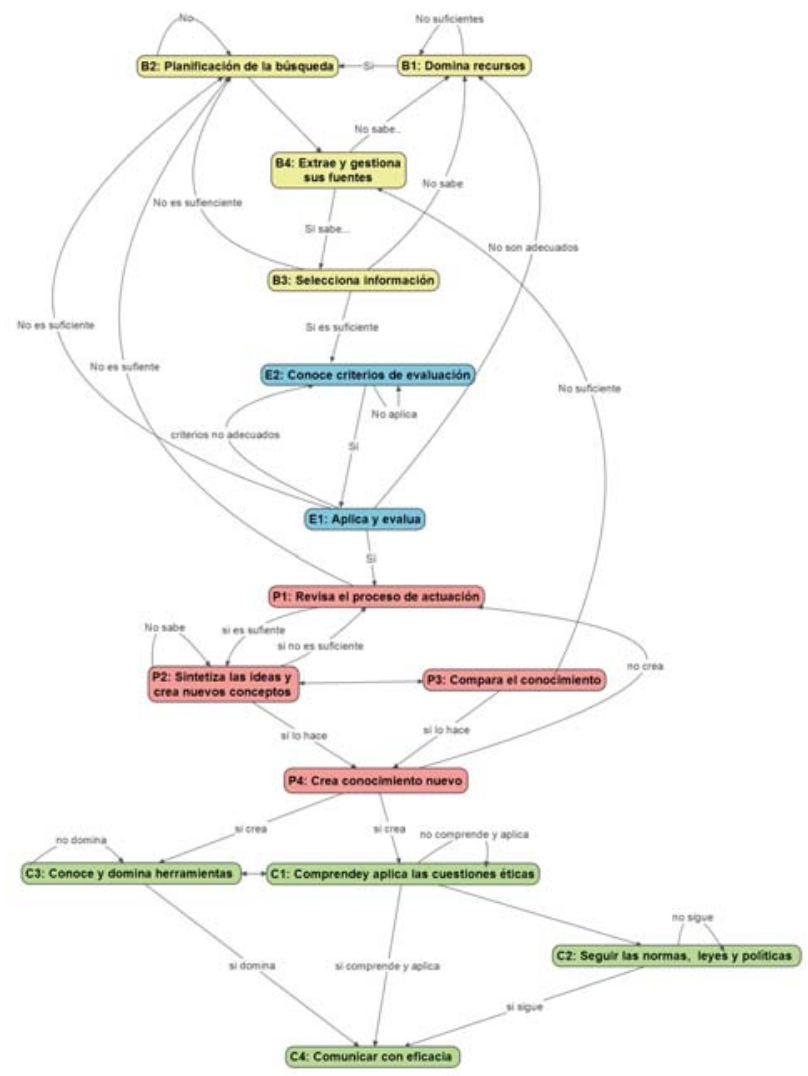

Figure 4. Flowchart

Dealing with the fourth phase, given that the average will be used as statistic of central tendency with the purpose of avoiding bias in relation with the nature of itself, the atypical extreme scores located (scores which are further than 3 times to the 


\section{Selection of key standards to create an instrument for information literacy assessment in Compulsory Secondary Education}

interquartile range of the variable) are removed in the first place. Specifically, 4 scores collected in 3 variables are removed.

The results obtained in this assessment phase of the importance of standards are as follows: the standard B1_02 (select information sources that better suit in the task to carry out) and P2_25 (extend the initial synthesis to a higher level of abstraction to construct new hypotheses that can require additional information) have an average of 9.43 points in both cases. However, the standard B3_10 (use the specialized services available at the institution to recover information needed personally or online) is the least assessed by the experts with an average of 6.93 points.

About the learning results, the standard that has the best valuation is $\mathrm{P} 2$ with a result of 8.97 , while the learning result $\mathrm{B} 3$ has the worst average with 7.54 points. In this phase, the dimension that obtains the best average of the four dimensions is the information process dimension, although the differences between the four dimensions are not relevant.

Between the maximum and minimum score, there is only half point of difference, because the four scores are between 8.2 and 8.7 points, in absolute terms.

Once obtained the final score through the weighing of the 3 scores got in each phase, it is observed that the standard P2_25 (extend the initial synthesis to a higher level of abstraction to construct new hypotheses that can require additional information) gets the best scores. Specifically, this standard is in the percentile 2, so that it leaves $98 \%$ of standards below itself in importance. By contrast, the standard B3 10 (use the specialized services available at the institution to recover information needed personally or online) is located in the last place of importance.

Table 1. Frequency of standards selection

\begin{tabular}{|c|c|c|}
\hline Dimension & Learning results & $\mathbf{n}_{\mathbf{i}} / \mathbf{n}$ \\
\hline \multirow{4}{*}{ Search } & B1: manage resources & $2 / 4$ \\
\hline & $\begin{array}{l}\text { B2: know how to do the search } \\
\text { planning }\end{array}$ & $3 / 4$ \\
\hline & B3: select information & $0 / 2$ \\
\hline & B4: extract and manage the sources & $0 / 2$ \\
\hline \multirow{2}{*}{ Assessment } & E1: apply and assess & $1 / 3$ \\
\hline & E2: know assessment criteria & 2/4 \\
\hline \multirow{4}{*}{ Process } & P1: review the process & $2 / 2$ \\
\hline & $\begin{array}{l}\text { P2: synthesize ideas and create new } \\
\text { concepts }\end{array}$ & $3 / 3$ \\
\hline & P3: compare new knowledge & $2 / 3$ \\
\hline & P4: create new knowledge & $1 / 2$ \\
\hline \multirow{4}{*}{ Communication } & $\begin{array}{l}\text { C1: understand and apply ethical } \\
\text { standards }\end{array}$ & $\mathbf{0} / \mathbf{3}$ \\
\hline & $\begin{array}{l}\text { C2: know the rules, laws and } \\
\text { policies }\end{array}$ & $1 / 3$ \\
\hline & C3: know and manage tools & $1 / 2$ \\
\hline & $\begin{array}{l}\text { C4: know how to communicate } \\
\text { effectively }\end{array}$ & $1 / 3$ \\
\hline
\end{tabular}

The table 1 shows the quantity of standards selected of each learning result. It is curious that the information search dimension has selected only 5 of 12 possible standards.

Furthermore, at the dimension of information assessment, only 3 of 7 standards are above the percentile 50 .

From 10 possible standards, at the information process dimension only 8 of them are selected. So, almost all standards are selected, based on the criteria. Then this dimension can be very important because is adding many standards for the assessment instrument.

Finally, if the previous dimension had the highest percentage standards, the dimension of communication information has the lowest percentage standards. In this dimension, only 3 of 11 standards are selected.

To analyze deeply these data through the standardized scores, it is necessary to obtain the average of the standards, learning results and dimensions. (Table 2).

Table 2. Average importance of standardized dimensions

\begin{tabular}{|c|c|c|c|}
\hline Dimension & Learning results & Xres & Xdim \\
\hline \multirow{4}{*}{ Search } & B1: manage resources & $\mathbf{0 , 2 3}$ & \multirow{4}{*}{$-0,09$} \\
\hline & $\begin{array}{l}\text { B2: know how to do the } \\
\text { search planning }\end{array}$ & 0,46 & \\
\hline & B3: select information & $-0,66$ & \\
\hline & $\begin{array}{l}\text { B4: extract and manage } \\
\text { the sources }\end{array}$ & $-0,40$ & \\
\hline \multirow[b]{2}{*}{ Assessment } & E1: apply and assess & $-0,10$ & \multirow[b]{2}{*}{$-0,01$} \\
\hline & $\begin{array}{l}\text { E2: know assessment } \\
\text { criteria }\end{array}$ & 0,09 & \\
\hline \multirow{4}{*}{ Process } & P1: review the process & 0,50 & \multirow{4}{*}{$\mathbf{0 , 2 0}$} \\
\hline & $\begin{array}{l}\text { P2: synthesize ideas and } \\
\text { create new concepts }\end{array}$ & 0,73 & \\
\hline & $\begin{array}{l}\text { P3: compare new } \\
\text { knowledge }\end{array}$ & $-0,08$ & \\
\hline & $\begin{array}{l}\text { P4: create new } \\
\text { knowledge }\end{array}$ & $-0,35$ & \\
\hline \multirow{4}{*}{ Comunicación } & $\begin{array}{l}\text { C1: understand and } \\
\text { apply ethical standards }\end{array}$ & $-0,45$ & \multirow{4}{*}{$-0,19$} \\
\hline & $\begin{array}{l}\text { C2: know the rules, } \\
\text { laws and policies }\end{array}$ & $-0,15$ & \\
\hline & $\begin{array}{l}\text { C3: know and manage } \\
\text { tools }\end{array}$ & $-0,03$ & \\
\hline & $\begin{array}{l}\text { C4: know how to } \\
\text { communicate } \\
\text { effectively }\end{array}$ & $-0,14$ & \\
\hline
\end{tabular}

At the level of the dimensions, the highest average is obtained from the information process dimension with 0.20 , while the lowest average is obtained from the information communication dimension. As regards to the information search dimension and the information assessment dimension it can be observed that both averages are nearly 0 .

If the dimensions are observed through its learning results, we can get interesting results. 


\section{Second International Conference on Technological Ecosystems for Enhancing Multiculturality - TEEM'14}

The information search dimension appears with 2 learning results with negative average and 2 positive averages. In this case, the general average of this dimension is negative because the negative average is higher than the positive.

In the positive average, the average of $\mathrm{B} 1$ is moderate, while in B2 is medium. In the negative average, B3 has a medium-high average (above 0.5 ) and B4 is medium.

The average of the information assessment dimension is nearly 0 . This is due to the learning result E1 has a negative moderate average, while E2 has a positive moderate average. Therefore, there are not many differences.

As shown above, the information process dimension has the highest average. This dimension is formed by 2 learning results which are higher than the average, with a moderate value (P1) and other with a medium-high value (P2); and 2 learning results which are lower than the average, whose average is practically 0 in one case (P3) and with a negative medium average in another case (P4).

Finally, it should be noted that at the information communication dimension all the averages of their learning results are negative.

$\mathrm{C} 1$ has -0.45 that is considered as a medium value, while other learning results are situated within the negative moderate average.

In addition, the scores obtained in the table 2 about the information literacy dimensions have little differences. It should be taken into account that the process, although slightly, seems to have more importance than the information communication dimension in the whole process.

\section{DISCUSSION AND CONCLUSION}

After examining and comparing the main handbooks of information literacy standards, it is concluded that each handbook uses its own criteria; therefore, there are some differences between them: different dimensions, handbooks based on cognitive skills, handbooks based on practice...

This research removes the information need dimension because it is considered implicit during the whole process of information. In this case, this research is similar to other researches $[8,36]$ that establish 4 dimensions of information literacy: information search dimension, information assessment dimension, information process dimension and information communication dimension.

Regarding the value of the dimensions established, in each of the phases that belong to the first part of this research, the information literacy dimensions contain various values depending on the phase.

In first place, in the phase 2, where the descriptors proposed by the Ministry of Education, Science and Sport are compared, the information search dimension is the most valuable. The same occurs in the phase 3, where the data are extracted from the flowchart. The information search dimension is the most valuable.

However, in the phase 4, the data obtained by experts on valuations show a change. The information process dimension is the most valuable.

This lack of consistency in the importance assigned to the dimensions in different phases can be due to the existence of some initial bias in the establishment of the standards or descriptors provided as by the handbooks $[11,14,38]$ as the proposal analyzed from the Ministry [31]. It also can be due to that the experts have another point of view, as they work at the university and have a different perspective of this topic.
Finally, the evidence obtained shows that there are dimensions which are more important than others are. At this case, the most important dimension is the information process dimension. This occurs because experts always have attributed this type of researches to Education Science or Evolutionary Psychology due to the researches performed previously, specifically some researches about the aspects of information process [2, 9, 44]. However, despite these differences, it is important to say that all dimensions are important because all of them are related to each other (as the flowchart shows in the phase 3).

As weaknesses of this study, it is important to highlight that 30 experts were invited to answer the questionnaire, but only 14 of them did it, so it can be an important source of slant. On the other hand, as it is the first part of the research, we must be careful with the value of the impact of this key standards selection, so generalizations must not be done yet.

About the future creation of the instrument, it has been possible to achieve the aims of the research at this stage. These aims consisted in establishing the key standards selection that allowed designing an assessment instrument of information literacy in Secondary Education, what can be the base of the information literacy assessment at this educational stage.

Then, the future line to research in relation with the design and validation of an assessment instrument of information literacy for students who are in Secondary Education is opened, and there are other lines of research which appear with the relations between the establishment and standardization of formal procedure. These last, have to allow the key standards to design assessment instruments for Elementary Education, with an extension and suitable content to the students' level.

\section{REFERENCES}

[1] AASL 2008. Standards for the 21st-century. Learner in Action. American Library Association.

[2] Acuña Castillo, S.R., García Rodicio, H. and Sánchez Miguel, E. 2011. Fostering active processing of instructional explanations of learners with high and low prior knowledge. European journal of psychology of education. 26, 4 (2011), 435-452.

[3] ALA 1989. American Library Association Presidential Committee on Information Literacy: final report. American Library Association.

[4] ALA/ACRL 2000. Information Literacy Competency Standards for Higher Education. Chicago IL: ACRL.

[5] ANZIIL 2004. Australian and New Zealand Information Literacy Framework: principles, standards and practice 2nd ed.

[6] Appleton, L. 2005. Examination of the impact of information-skills training on the academic work of health-studies students: a single case study. Health Information and Libraries Journal. 22, 3 (2005), 164-172.

[7] Baker, E. 2006. Managing in the information age: preventing «electronic fatigue syndrome». Journal of Public Health Management and Practice. 12, 3 (2006), 298-300.

[8] Becerril Balín, L. and Badía, A. 2013. La Competencia Informacional en la Educación Secundaria. Demanda de aprendizaje y resolución colaborativa de problemas relativos a la información con apoyo de las TIC. Revista de Educación. 362 (2013), 659-689.

[9] Beishuizen, J.J. and Stoutjesdijk, E.T. 1999. Study strategies in a computer assisted study environment. Learning and Instruction. 9, 3 (1999), 281-301. 
[10] Blasco Olivares, A. and Durban Roca, G. 2012. La competencia informacional en la enseñanza obligatoria a partir de la articulación de un modelo específico. Revista Española de Documentación Científica. (2012), 100-135.

[11] Bundy, A. and ANZIIL 2004. Australian and New Zealand information literacy framework principles, standards and practice. Australian and New Zealand Institute for Information Literacy.

[12] Burkhardt, J.M., MacDonald, M.C. and Rathemacher, A.J. 2003. Teaching information literacy: 35 practical, standards-based exercises for college students. American Library Association.

[13] Calvani, A., Cartelli, A., Fini, A. and Ranieri, M. 2008. Models and Instruments for Assessing Digital Competence at School. Journal of e-Learning and Knowledge Society. 4, 3 (2008), 183-193.

[14] CAUL 2001. Information literacy standards. University of South Australia.

[15] CRUE-TIC \& REBIUN 2009. Competencias informáticas e informacionales en los estudios de grado.

[16] CRUE-TIC \& REBIUN 2013. Manual para la formación en competencias informáticas e informacionales (CI2).

[17] Delors, J. 1997. La educación encierra un tesoro: informe a la UNESCO de la Comisión Internacional de la Educación para el Siglo XXI. UNESCO.

[18] Diario oficial de la Unión Europea 2006. Recomendación del Parlamento Europeo y del Consejo de 18 de diciembre de 2006 sobre las competencias clave para el aprendizaje permanente. Parlamento Europeo y Consejo de la Unión europea.

[19] Dini, P., Iqani, M. and Mansell, R. 2011. The (im)possibility of interdisciplinarity: lessons from construting a theoretical framwork for digital ecosystems. Culture, theory and critique. 52, 1 (2011), 3-27.

[20] Ferrari, A. 2013. DIGCOMP: a framework for developing and understanding digital competence in Europe. Publications Office of the European Union.

[21] Fuentes Agustí, M. and Monereo, C. 2008. Cómo buscan información en Internet los adolescentes. Investigación en la escuela. 64 (2008), 45-58.

[22] González, L., Marciales, G., Castañeda-Peña, H. and Barbosa-Chacón, J. 2013. Competencia informacional: desarrollo de un instrumento para su observación. Lenguaje. 41, 1 (2013), 105-131.

[23] Grant, M.J. and Brettle, A.J. 2006. Developing and evaluating an interactive information skills tutorial. Health Information and Libraries Journal. 23, 2 (2006), 79-86.

[24] Head, A.J. and Eisenberg, M. 2009. How college students seek information in the digital age. The Information School, University of Washington.

[25] ISTE 2007. National Educational Technology Standards for Student.

[26] Kabachinski, J. 2004. Coping with information fatigue syndrome. Biomedical Instrumentation \& Technology. 38, 3 (2004), 209-12.

[27] Kuiper, E., Volman, M. and Terwel, J. 2009. Developing Web literacy in collaborative inquiry activities. Computers \& Education. 5, 3 (2009), 668-680.

[28] LOE 2006. Ley Orgánica de Educación (LOE) 2/2006, de 3 de mayo. En BOE de 4 de mayo de 2006.

[29] LOMCE 2013. Ley Orgánica para la Mejora de la Calidad Educativa (LOMCE) 8/2013, de 9 de diciembre. En BOE de 10 de diciembre de 2013.
[30] Martínez Clares, P. and Echeverría Samanes, B. 2009. Formación basada en competencias. Revista de Investigación Educativa. 27, 1 (2009), 125-147.

[31] Ministerio de Educación, Cultura y Deporte 2013. Guía para la formación en centros sobre las competencias básicas. Centro Nacional de Innovación e Investigación Educativa (CNIIE).

[32] Oppenheim, C. 1997. Managers' use and handling of information. Internacional Journal of Information Management. 17, 4 (1997), 246.

[33] Piaget, J. 1973. Estudios de psicología genética. Emecé Editores.

[34] Piaget, J. 1975. Seis estudios de psicología. Barcelona. Seix Barral.

[35] Pifarré, M., Sanuy, J., Vendrell, C. and Gòdia, S. 2009. Internet en la educación secundaria: pensar, buscar y construir conocimiento en la red. Milenio.

[36] Pinto Molina, M. 2009. Design of the IL-HUMASS survey on information literacy in higher education: A selfassessment approach. Journal of Information Science. 36, 1 (2009), 86-103.

[37] Pinto Molina, M., Uribe Tirado, A., Gómez Díaz, R. and Cordón, J.A. 2011. La producción científica internacional sobre competencias informacionales e informáticas: tendencias e interrelaciones. 25 (2011), 29-62.

[38] Presidential Committee on Information Literacy: Final Report: 1989. http://www.ala.org/acrl/publications/whitepapers/presiden tial. Accessed: 2014-06-03.

[39] Rangachari, P.K. and Rangachari, U. 2007. Information literacy in an inquiry course for first-year science undergraduates: a simplified $3 \mathrm{C}$ approach. Advances in Physiology Education. 31, 2 (2007), 176-179.

[40] Rodríguez Conde, M.J., Olmos Migueláñez, S. and Martínez Abad, F. 2013a. Autoevaluación de competencias informacionales en educación secundaria: propuesta de modelo causal desde una perspectiva de género. Bordón. Revista de pedagogía. 65, 2 (2013a), 111126.

[41] Rodríguez Conde, M.J., Olmos Migueláñez, S. and Martínez Abad, F. 2013b. Evaluación de competencias informacionales en educación secundaria: un modelo causal. Cultura y Educación. 25, 3 (2013b), 361-373.

[42] Rodríguez Conde, M.J., Olmos Migueláñez, S. and Martínez Abad, F. 2012. Propiedades métricas y estructura dimensional de la adaptación española de una escala de evaluación de competencia informacional autopercibida (IL- HUMASS). Revista de Investigación Educativa. 30, 2 (2012), 347-365.

[43] Rodríguez Conde, M.J., Olmos Migueláñez, S., Pinto Molina, M., Martínez Abad, F. and García Riaza, B. 2011. Informational literacy and information and communication technologies use by secondary education students in spain: a descriptive study. Contemporary Issues in Education Research (CIER). 4, 4 (2011), 1-12.

[44] Rosales, J., Sánchez Miguel, E. and Pérez, J.R.G. 2004. Interacción profesor-alumno y comprensión de textos: el papel del profesor en la organización de la responsabilidad conjunta. Revista de Educación. 334 (2004), 347-360.

[45] Saito, H. and Miwa, K. 2007. Construction of a learning environment supporting learners' reflection: A case of information seeking on the Web. Computers \& Education. 49, 2 (2007), 214-229. 
Second International Conference on Technological Ecosystems for Enhancing Multiculturality - TEEM'14

[46] Sauvajol-Rialland, C. 2013. Infobésité: Comprendre et maîtriser la déferlante d'informations. Viubert.

[47] SCONUL 2001. Information skills in higher education: a SCONUL position paper. SCONUL.

[48] Thomas, S. 1998. Information fatigue syndrome. Is there an epidemic? Issues in mental health nursing. 19, 6 (1998), 523-524.

[49] Toffler, A. 1970. Future Shock. Random House.

[50] Torrecilla Sánchez, E., Martínez Abad, F., Olmos Migueláñez, S. and Rodríguez Conde, M.J. 2014.
Formación en competencias básicas para el futuro profesorado de educación secundaria: competencias informacionales y de resolución de conflictos. Profesorado, Revista de Currículum y Formación del Profesorado. 18, 1 (2014).

[51] Zeldes, N. 2009. Infoglut: It's the disease of the new millennium. How do we treat it? IEEE Spectrum. 46, 10 (2009), 30-32 52. 